46 Literatura e Sociedade

\title{
GiovanNi Verga e a CONSTRUÇÃO DO VERISMO
}

\author{
Ana Paula Freitas de Andrade
}

Universidade de São Paulo

Resumo

Este artigo trata da construção e da trajetória do Verismo italiano, focalizando, especialmente, o papel desempenhado por Giovanni Verga nesses processos.

Abstract

This article is about the construction and the trajectory of the italian Verism, focusing, specially, on the role performed by Giovanni Verga in these processes.
Palavras-chave

Verismo;

Giovanni

Verga;

naturalismo;

narrador

impessoal;

paródia.

Keywords

Verism;

Giovanni Verga;

naturalism;

impersonal

narrator;

parody. 
erga publicou Os Malavoglia, obra-prima do verismo, em fevereiro de 1881. A primeira edição do romance não alcançou o mesmo sucesso das últimas publicações do escritor siciliano. Numa carta que enviou ao amigo e também escritor Luigi Capuana, Verga queixava-se do "fracasso total" do seu romance e da indiferença do público italiano, que se dizia amante de literatura. ${ }^{1}$ Pouco depois, numa resenha publicada no Fanfulla della Domenica, Capuana afirmava que Os Malavoglia eram um romance de vanguarda, que tinha alcançado o ideal da impessoalidade narrativa, como nenhum outro romance moderno. ${ }^{2}$

O silêncio da crítica e a indiferença do público, que perduraram por mais de vinte anos, podem ser creditados tanto ao caráter inovador da obra como a uma série de preconceitos que sempre marcaram as relações entre o norte e o sul da península, e foram exacerbados durante o processo de assimilação das diferenças socioeconômicas e culturais da Itália recém-unificada. Certamente, a língua criada por Verga para narrar as desditas da família Malavoglia, resultado de uma ousada "sicilianização" do italiano, desgostava à crítica conservadora da época, e afastava o público, acostumado ao italiano como padrão literário. Somente no século XX, a crítica "descobriu" Os Malavoglia, a partir de um ensaio de Benedetto Croce, publicado no primeiro número de sua revista La Critica. As gerações seguintes passaram a reconhecer o autor como "mestre do Verismo", e o romance, como clássico da literatura italiana.

Desde meados da década de 1870, a dupla Verga e Capuana participava da vida artístico-intelectual milanesa, divulgando materiais literários de caráter natu-

${ }^{1}$ Gino Raya (org.) Lettere a Luigi Capuana, Firenze, Felice Le Monnier, 1975, p. 168-170 (carta de 11 abr. 1881).

2 Corrado Simioni, "Introduzione", in Giovanni Verga, I Malavoglia, Milano, A. Mondadori Ed., 1978, p. 21. 
ralista, de origens francesa, inglesa e russa. Quando não estavam na mesma cidade, mantinham intensa correspondência entre si e também com outros literatos - Felice Cameroni, Salvatore Farina, Emilio Treves, e integrantes do grupo dos scapigliati -, em que discutiam as novas ideias, e as maneiras de aplicá-las à própria criação literária, adaptando-as ao contexto italiano. O plano de elaborar uma versão nacional da literatura naturalista assumia importância capital na vida dos dois escritores sicilianos, e sua atuação, juntamente com os colegas mais chegados, fez que o verismo começasse a adquirir contornos próprios. Luigi Capuana, chamado "profeta do naturalismo", empenhou-se em promover a obra e as concepções de Zola. Escreveu uma série de ensaios, estudos e artigos sobre a temática naturalista, e é autor de Giacinta, publicado em 1879 e reconhecido como o primeiro romance verista.

$\mathrm{Na}$ tentativa de investigar e compreender as forças que condicionam as circunstâncias espirituais, econômicas, culturais da vida diária e geram os movimentos histórico-sociais, a expressão literária naturalista privilegiava a representação da realidade em seus estratos mais profundos e abrangentes. Na Itália, onde ocorria um processo de unificação política conturbado, e a urbanização e a industrialização desenvolviam-se de forma desigual nas regiões Norte e Sul, foi a sociedade rústica e atrasada das províncias sicilianas que atraiu o olhar dos veristas.

Em 1874, com a publicação do conto Nedda ${ }^{3}$ Verga inaugurou o principal filão temático do verismo: a vida de camponeses e pescadores nas províncias sicilianas, sob condições de sobrevivência extremamente precárias, regida por estruturas e costumes arcaicos, afligida por antigas mazelas sociais e vítima de sequelas do processo de Unificação italiano. Ao explorar esse novo cronotopo literário, o autor experimenta tendências artísticas, elementos narrativos e técnicas de composição que viriam a se estabilizar no repertório da literatura verista: a apropriação de temas e motivos culturais populares, a reprodução da linguagem falada regional na prosa literária, a descrição minuciosa dos costumes e do cotidiano do homem comum, o desenvolvimento do enredo narrativo de acordo com princípios de dois sistemas filosóficos relevantes do século XIX, o positivismo de Auguste Comte e o pessimismo de Arthur Schopenhauer.

O narrador de Nedda dá início à fabulação com um breve prólogo em primeira pessoa, por meio do qual prepara o leitor, burguês como ele, para um espetáculo de "atmosferas desconhecidas" "que o deixará com cabelos brancos e rugas no rosto. Numa poltrona confortável junto à lareira, o narrador convida o leitor a acompanhar o seu espírito que vagabundeia por caminhos inusitados, até chegar a uma pequena propriedade rural perto do Etna, onde a história se passa. É um povoado miserável, e a protagonista Nedda parece ser a mais desgraçada de todos. O tema da história é a luta desigual da camponesa contra a miséria e a morte, que

${ }^{3}$ Publicado originalmente na Rivista italiana di Scienze, Lettere ed Arti, de Milão, em 15 de junho.

${ }^{4}$ G. Verga, "Nedda", Tutte le novelle, novelle (a cura di Lina e Vito Perroni), Milano, A. Mondadori Editore, 1940, v. I, p. 14. 
paulatinamente vão-lhe tomando os entes mais próximos - a mãe, o namorado, a filha recém-nascida -, até a deixarem só e desamparada. Tanto a encenação inicial armada pelo narrador quanto o assunto evocam os tradicionais serões invernais entre familiares e amigos, em que eram desfiados os racconti di veglia - contos maravilhosos, frutos da cultura popular apenínica.

A abertura do conto, impregnada de um lirismo aconchegante, funciona como uma antessala da história a ser narrada, uma zona neutra em que o narrador preserva o leitor e a si mesmo a uma boa distância do universo que ele passará a narrar, assumindo então uma voz em terceira pessoa. É como se, à realidade crua e mísera só fosse permitido o tratamento literário sério por meio desse processo de adequação, em que uma história incômoda é revestida de uma outra aprazível que a justifica.

Embora o conto descreva uma faceta da sociedade siciliana sob forte acondicionamento romântico, que faz que o narrador se mantenha diferenciado do mundo que representa e confronte realidade e idealidade, a narrativa experimenta princípios compositivos da escola naturalista francesa, desde já temperados à moda italiana. A começar pelo papel de protagonista concedido a uma camponesa do mais baixo escalão de sua classe social, Nedda vive de expedientes, nem sempre consegue trabalho, não tem como comprar os remédios para a mãe doente, $\mathrm{e}$ nem o pão de cada dia. O retrato dessa comunidade arcaica é traçado de acordo com o método desenvolvido por Balzac, definido como "estudos dos costumes", que privilegia a descrição de hábitos e usos do presente, "com tudo o que tiver de cotidiano, prático, feio e comum". 5 É o que Verga faz, ao descrever as agruras do trabalho no campo, a parca refeição no fim do dia, as conversas de poucas palavras, orientadas pela lógica do senso comum, o comportamento das pessoas regido pela fé cega nos preceitos católicos.

No conto, predomina a forma narrativa convencional (do narrador burguês que conta a história ao pé da lareira), e a representação da língua falada do grupo social retratado se dá pela reprodução de algumas expressões dialetais, termos do trabalho, o trecho de uma cançoneta popular e alguns provérbios da região, que, tanto no discurso direto quanto no indireto, aparecem destacados por grifo - recurso que resguarda o nível culto da língua literária, sem deixar de dar uma amostra da língua local.

A representação da hierarquia da comunidade social obedece aos critérios darwinistas da seleção natural. No dia de pagamento do trabalho, recebem-no primeiramente os homens turbulentos, em seguida as mulheres briguentas, e por último as tímidas e fracas. A equiparação entre seres humanos e animais é recorrente, Nedda parece um passarinho assustado, corre feito uma cabrita tresmalhada ou trabalha como uma formiga, e seu namorado migra de cá pra lá como a cotovia em busca de milho. A sucessão ininterrupta de desgraças, que culmina na

${ }^{5}$ E. Auerbach, Mimesis - A representação da realidade na literatura ocidental, São Paulo, Perspectiva, 1971, p. 430. 
resignação trágica da protagonista ao sofrimento da vida, já engendra a lógica pessimista, típica do verismo.

A opção do autor por explorar argumentos de um novo campo sociocultural implica a criação de padrões estéticos, soluções estilísticas e recursos narrativos que os comportem e representem o novo objeto literário com propriedade. Ao serem introduzidos conteúdos inéditos na literatura, desencadeia-se uma crise na criação estética que leva à superação da própria arte; ${ }^{6}$ e dessa perspectiva, entende-se que ao colocar em prática as concepções artísticas que defendia, Verga contribuiu não somente para a construção do verismo, mas também para a renovação dos fundamentos da "literaturidade e da poeticidade dominantes" em seu país. O conto Nedda configura-se como o anúncio do rompimento das convenções vigentes na literatura italiana da época, porque agrupa em gérmen as propostas de inovação da criação literária, as quais, ao longo dos anos subsequentes, passariam a fazer parte do preceituário do verismo.

Entre 1875 e 1880, Giovanni Verga trabalhou concomitantemente na redação do romance Os Malavoglia e de alguns contos, ${ }^{8} \mathrm{em}$ que criou um numeroso elenco de personagens sicilianos típicos. "Fantasticheria" e "Lamante di Gramigna" são material precioso para o estudo dos métodos de representação verguianos e da própria trajetória da escola verista. Além desses contos, as várias etapas de criação de Os Malavoglia consubstanciam a experimentação do escritor em busca do narrador impessoal perfeito, ao mesmo tempo que dão uma amostra de suas reflexões sobre o significado e a funcionalidade das proposições artísticas, de caráter naturalista, que iriam revolucionar a literatura italiana nas últimas décadas do século XIX.

O conto "Fantasticheria", além de antecipar o argumento de Os Malavoglia, ganha ares de manifesto verista, uma vez que o seu objetivo não é propriamente narrar uma história, mas sim discutir concepções e métodos literários inovadores, inspirados na práxis do naturalismo francês, que são ilustrados com breves quadros narrativos, adaptados ao conteúdo temático da realidade sociocultural italiana.

O autor-narrador apresenta o texto como uma carta em resposta a um pedido de uma signora da alta sociedade setentrional, com a qual tivera um romance fugaz num cenário idílico à beira-mar de Aci Trezza, onde ela, depois de um primeiro momento de encanto e excitação, logo ficara entediada. Na prática, "Fantasticheria" é uma carta aberta ao leitor burguês, com a intenção de introduzir um espetáculo literário inusitado, a representação realista de uma pequena comunidade da costa siciliana. O narrador adverte o público de que o espetáculo pode causar tanto estranheza quanto divertimento. O título já desvela a ironia fina e o

${ }^{6}$ Cf. M. Bakhtin, Estética da criação verbal, São Paulo, Martins Fontes, 2003, p. 215-216.

${ }^{7}$ M. Bakhtin, Questões de literatura e de estética (A teoria do romance), São Paulo, Hucitec, Unesp, 1988, p. 403

${ }^{8}$ Reunidos em Primavera e altri racconti (1876) e Vita dei Campi (1880).

${ }^{9}$ As publicações originais desses contos, em periódicos, são de 1879 e 1880 , respectivamente. 
tom sofisticado da denúncia social que permeiam a narrativa: para a burguesia, que passa a galope e vê superficialmente a vida vagarosa e simples da província, é fácil se dar ao capricho de tomá-la por motivo de diversão intelectual. Como se o resultado da representação literária da existência "dessa gente sem eira nem beira" fosse pura fantasia e não correspondesse à realidade concreta de um grupo desfavorecido nos aspectos materiais, sociais e espirituais da existência.

Uma das propostas mais interessantes do conto é preparar os leitores para uma óptica literária inédita, que ajusta o foco em um novo objeto artístico. O narrador convida a "gente di toga" a olhar pelo microscópio o pequeno mundo da "gente di mare" de Aci Trezza. ${ }^{10}$ Logo de saída, explicitando o caráter positivista da narrativa, ele se mune de princípios científicos para estabelecer um ponto de vista imparcial, a partir do qual desenvolve a representação literária realista da comunidade. A narrativa sustenta um jogo sutil de lentes entre a fantasia da burguesia e a realidade crua dos miseráveis. A primeira não enxerga a segunda a olho nu, e esta, por sua vez, ofusca-se bestificada perante a miragem da opulência burguesa.

O narrador-observador focaliza uma célula social, uma família de pescadores, trazendo à tona as suas pequeninas causas. Expõe o nó do drama dos pequenos, como os chama, e se propõe a desenvolvê-lo num romance a ser publicado futuramente. Ao descrever o lugar e a população, que tem a pele mais dura que a casca do pão que come, o narrador debuxa o universo ficcional de Os Malavoglia (no qual Verga já trabalhava): o velho avô, timoneiro, que morre sozinho no hospital; a mocinha que espia por detrás do arbusto de manjericão; o pai e o filho marujos, vítimas fatais de naufrágios; a mulher que vende laranjas numa banquinha na rua; a mendiga que pede esmola na praça; aqueles que "comem o pão do rei",;1 o médico que chega montado num burrico; a casa onde falta a nespereira, já cortada; a taverneira, e a porta do seu estabelecimento abarrotada de gente em dia de chuva; os rochedos gigantescos que guardam o sofrimento e a carência do povo. A análise da sociedade local não foge ao viés positivista, o narrador compara-a com um exército de formigas: homens e insetos subjugados às mesmas e inexoráveis leis do instinto animal. A natureza reina soberana nesse ambiente, onde os pequeninos nada podem fazer para refrear a sua fúria, que toma forma de borrascas, tempestades, ou ainda de pestes que periodicamente varrem o formigueiro humano.

"Non capisco come si possa vivere qui tutta la vita"12 é a questão que a distinta signora coloca, quando começa a se entediar, durante sua breve estada na aldeia. O narrador toma-a como mote e, a partir da premissa de que basta não dispor de cem mil liras para viver ali eternamente, desenvolve o "ideal da ostra"13 - uma alegoria filosófica de teor positivista e prognóstico pessimista, que se estabelece

\footnotetext{
${ }^{10}$ G. Verga, "Fantasticheria", Tutte le novelle, op. cit., p. 146.

${ }^{11}$ Idem, ibidem.

${ }^{12}$ Idem, ibidem.

${ }^{13}$ Idem, ibidem. p. 151.
} 
como estatuto da existência ficcional do elenco malavogliano e, de uma maneira geral, de toda a linhagem de personagens de obras veristas. A teoria de Verga interpreta a malfadada vida da gente do mar, com base na ideia positivista, já esboçada em Nedda, de que o ambiente natural determina as condições da vida humana. O narrador faz uma recriação metafórica da gênese dos seres, ao supor que enquanto o destino semeava príncipes e duquesas aqui e ali, deixou cair entre os rochedos essa pobre gente, que, numa atitude corajosa, agarrou-se aos escolhos, resignando-se a uma vida destinada a miséria, ignorância e desgraça. O arrimo da comunidade é a "religião da família"14 que invariavelmente, de pai para filho, reverencia o trabalho, a casa e as pedras que a circundam. Para o autor, o drama ganha dimensão literária quando a cobiça pelo bem-estar atinge um dos pequeninos corações, talvez o mais fraco ou incauto, a ponto de inspirar-lhe desejos que o projetam para além do seu círculo social e o fazem romper com o restrito código moral da comunidade.

No sistema linguístico do conto, predomina a linguagem literária culta, permeada por um leve tom de informalidade, por se tratar da representação da correspondência íntima entre interlocutores burgueses. O narrador refere-se ao dialeto siciliano como semibárbaro e as poucas expressões locais que emprega - "gente di mare", "gente di toga", "sotto le sue tegole", "occhiata di sole", "nei guai", "mangiano il pane del re" - figuram entre aspas, como a delimitarem dois planos linguísticos distintos: o alto e o baixo; aos quais correspondem duas realidades sociogeográficas do país, radicalmente desiguais: lassù e laggiù. A organicidade linguística do conto está de tal forma amarrada à realidade social da Itália pós-unitária, que faz saltar aos olhos a fronteira invisível que, à revelia do processo de unificação política (e mesmo à custa dele), ainda divide a sociedade italiana em duas facções: a do norte, privilegiada, e a do sul, desfavorecida.

Verga não perde de vista as crises internas do país e as denuncia ao público com paciência didática. Ao botar o dedo na ferida nacional, prática timidamente inaugurada em Nedda e que vai se tornando mais incisiva em Vita dei campi e Os Malavoglia, o escritor pretende não só sanar um quadro social desequilibrado, mas também educar o senso crítico dos leitores, que em matéria de literatura ainda preferia as amenidades e o melodrama ${ }^{15}$ à representação realista das questões sociais urgentes. É interessante notar os cuidados, em doses homeopáticas, que Giovanni Verga ministra para legitimar um tratamento literário sério à problemática sociopolítica italiana e, ao mesmo tempo, cativar o espírito do público, experimentando progressivamente conceitos e procedimentos artísticos, que aos poucos abrem caminho para a prática literária naturalista na Itália e criam condições à consolidação do verismo. Verga comemora essa conquista com o amigo Capuana, numa carta de março de 1879, na qual avalia que todo o esforço tinha resultado num bom avanço, mas ainda deveriam "malhar muito o ferro" para que seus

\footnotetext{
${ }^{14}$ Idem, ibidem.

${ }^{15}$ Cf. G. Petronio, Lattivitá letteraria in Italia, Milano, Garzanti, 1990, p. 710.
} 
propósitos fossem compreendidos, e eles finalmente pudessem ser aplaudidos em vez de apedrejados. ${ }^{16}$

Em "Lamante di Gramigna", outra face da crise social da Itália pós-unitária é exposta. Divide-se em duas partes: a primeira é uma introdução dedicada ao escritor Salvatore Farina, em que se discute o critério da verdade psicológica como argumento principal de uma nova literatura, e aborda a problemática da impessoalidade no romance moderno; a segunda é a história de Peppa e seu amante, o brigante Gramigna.

$\mathrm{Na}$ introdução, o autor explica que se trata de uma narração popular de valor histórico, um "documento humano", ${ }^{17}$ que ele reproduz tal e qual ouviu nas ruas. "Parecchi anni or sono, laggiù lungo il Simeto, davano la caccia a un brigante, certo Gramigna." ${ }^{18}$ A história é situada em pleno desenrolar do Banditismo Meridional, e retrata a caçada a um líder brigante. Gramigna é perseguido por toda a força militar da região, e suas proezas e insubordinação extraordinárias geram lendas que correm toda a província, inspirando à população sentimentos contraditórios de admiração e medo. A aura lendária de Gramigna eleva-o à condição de herói popular e seduz a bela Peppa, que está de casamento marcado com um dos melhores partidos do lugar, o compadre Finu. Fascinada pela lenda, a moça abandona a mãe, o noivo e o enxoval para juntar-se ao bandido. Quando Peppa se desgarra da comunidade, rompe com a "religião da família", dando início a toda uma sorte de desgraças. Junto a Gramigna, a jovem leva uma vida degradante; e depois de lutas sangrentas e fugas arriscadas, finalmente os dois são capturados. A mãe de Peppa vende tudo para pagar o advogado e tirá-la da prisão. Ela volta à casa materna com um filho de Gramigna nos braços, e lá permanece, como uma fera enjaulada, até que a mãe morre de desgosto. Na calada da noite, Peppa abandona a criança à roda dos expostos e vai para a cidade onde ouvira dizer que Gramigna estava preso. Pouco depois, fica sabendo que o amante foi transferido para um lugar distante, e só lhe resta então "ganhar o pão" por ali mesmo, prestando serviços aos soldados.

Como se trata da estilização paródica de uma lenda, Verga sincroniza dois planos narrativos e dois tipos de narrador: um conto escrito pelo autor burguês para o leitor burguês, que reproduz uma lenda contada por um narrador popular para pessoas do povo. No ponto em que ocorre a defasagem desses planos, em que cada um se resguarda à sua própria natureza, tornam-se evidentes os diferentes modos de transmissão de conhecimento e experiência narrativa de um e de outro. De um lado, o escritor burguês experimenta uma técnica narrativa e conceitos artísticos inusitados, com o propósito de educar a burguesia para uma literatura e uma consciência social novas; de outro, o narrador naturalista estiliza o narrador popular, que conta uma parábola anônima e transmite um preceito moral, cuja

\footnotetext{
${ }^{16}$ Gino Raya (org.) Lettere a Luigi Capuana, op. cit., p. 117.

${ }^{17}$ Em "Lamante di Gramigna", in G. Verga, Tutte le novelle, op. cit., p. 203.

${ }^{18}$ Idem, ibidem, p. 204.
} 
finalidade é perpetuar a tradição, educando a comunidade para a preservação da cultura e dos valores.

A lenda é um gênero narrativo composto de elementos que povoam o imaginário popular, e, nesse sentido, a história de Peppa e Gramigna expressa simbolicamente medos e temores que assombram a província siciliana no período pósunitário: miséria, fome, doença, prostituição, desagregação familiar, desamparo social e carência de perspectiva existencial. Verga expõe camadas mais profundas e sutis da ferida social da Itália recém-unificada, haja vista a declaração que faz na introdução do conto, afirmando que seu interesse maior concentra-se no estudo e na representação literária séria dos fenômenos psicológicos da sociedade.

Outro procedimento artístico experimentado no conto e desenvolvido de forma mais produtiva em Os Malavoglia, que atua no âmbito das verdades interiores com a intenção de desconstruir valores impostos pela tradição religiosa, é a construção de personagens centrais a partir da paródia de legendas de santos e mártires da fase inicial do cristianismo, os quais são patronos da região em que a história se passa, e protetores de profissões, atividades ou costumes típicos do lugar. Peppa, por exemplo, é comparada à padroeira das prostitutas arrependidas, ${ }^{19}$ "lei che ci aveva dell'oro quanto Santa Margherita!". ${ }^{20}$ Nesse processo de representação paródica, a trajetória da vida, as provações e o destino que o enredo reserva à personagem correspondem, até certo ponto, àqueles da legenda. Ao parodiar hagiografias, o autor reporta para o seu texto características marcantes do gênero, e organiza-as na estrutura narrativa em prol da despersonalização do narrador e intensificação da verossimilhança. A forma hagiográfica parte do princípio de que seu objeto de representação é pouco verossímil, e para que a narrativa inspire credibilidade, requer uma espécie de renúncia resignada do autor. Para lidar com a inadequabilidade do objeto é elaborada uma voz narrativa que abre mão da individualidade autoral para ressoar numa frequência comum, de generalização. De acordo com essa perspectiva, o narrador verista ao mesmo tempo que intensifica a marca de impessoalidade no discurso, desfruta da "autoridade indiscutível" ${ }^{11} \mathrm{da}$ hagiografia, para adentrar o imaginário do leitor, sem que esse imponha restrições. No que diz respeito à representação realista dos fenômenos psicológicos pretendida por Verga, o recurso cai como uma luva, pois retrata a mentalidade ultrapassada e as limitações imutáveis da vida desse grupo social, por meio da paródia de seus próprios ícones e valores religiosos.

As linhas que Giovanni Verga dedica a Farina têm, como "Fantasticheria", um quê de manifesto verista, porque, além de apresentarem as intenções programáticas do escritor, são redigidas na primeira pessoa do plural, sugerindo que é portavoz de um grupo que desenvolve uma nova literatura. "Noi rifacciamo il processo artistico al quale dobbiamo tanti monumenti gloriosi" 22 - seu discurso não rejeita a

\footnotetext{
${ }^{19}$ Cf. www.santiebeati.it.

${ }^{20}$ G. Verga, "LAmante di Gramigna", op. cit., p. 208.

${ }^{21}$ Cf. M. Bakhtin, Estética da criação verbal, op. cit., p. 170.

${ }^{22}$ Em G. Verga, "Lamante di Gramigna", op. cit., p 203.
} 
tradição romântica, antes, digere-a para dar continuidade à exploração de um argumento antigo, "o fato humano", marcado pelas "lágrimas verdadeiras, febres e sensações que passaram pela carne". ${ }^{23}$

As palavras do autor traduzem a visão de mundo do "eu naturalista", que procura equilibrar razão e emoção num só corpus fisiológico. Ao argumentar que o verdadeiro "fato humano" é de natureza psicológica, demonstra que os critérios do seu método de criação não se restringem à compreensão de uma representação realista apegada somente à realidade concreta, a qual apenas "reproduz a fachada" e "auxilia na produção do engodo", 24 mas sim, privilegiam a representação que explora a psicologia dos indivíduos. De acordo com a concepção do escritor, se o fato verdadeiro é o psicológico, a consciência do artista que o representa não é menos verdadeira; e a subjetividade do autor se traduz em objetividade, dado que a percepção psicológica e a concepção artística da realidade atuam num mesmo plano de representação.

Na teoria e na prática, como nos mais bem sucedidos contos de Vita dei campi e no romance Os Malavoglia, Verga propõe a observação dos caracteres das personagens e dos valores morais atuantes em cada situação, por meio de um processo dedutivo, em que a inferência do leitor é essencial para que o ambiente e as condições exteriores que condicionam o universo ficcional sejam depreendidos. De acordo com esse método, os fenômenos psicológicos são veiculados na narrativa a partir da consciência do autor, que se dá conta e se apropria das forças subjacentes atuantes no momento e no lugar em que a história se passa. O narrador descreve as personagens em situações corriqueiras e de interação entre si, de modo que as qualidades e os valores internos individuais revelam-se naturalmente e atuam por si na representação da realidade social e material a que estão submetidas. Esse método de criação privilegia a representação da fisiologia do espírito humano, de forma integrada a um contexto de amplitude antropológica.

Em carta de abril de 1878, Verga contava ao amigo Salvatore Paola Verdura sobre um grande projeto literário, em que pretendia compor um ciclo de cinco romances, intitulado Marea. A obra representaria a fisionomia da sociedade italiana moderna e traçaria a "fantasmagoria da luta pela vida", ${ }^{25}$ valendo-se dos métodos naturalistas da observação imparcial, minuciosa e da narração impessoal. De acordo com seu plano, cada romance estudaria uma classe social, desde a mais ínfima, onde a luta é "limitada ao pão cotidiano", ${ }^{26}$ até a mais luxuosa, onde a cobiça e a avidez regem os propósitos humanos. No prefácio a Os Malavoglia, Verga deu novo título ao ciclo, I vinti (Os vencidos), porém das cinco obras programadas, respectivamente I Malavoglia, Mastro Don Gesualdo, Duchessa di Leyra,

${ }^{23}$ Idem, ibidem

${ }^{24}$ Cf. Adorno, Notas de literatura I, São Paulo, Livraria Duas Cidades, Editora 34, 2003, p. 57.

${ }^{25}$ Apud C. G. Lanza, "Invito alla lettura", in: G. Verga: I grandi romanzi e tutte le novelle, Roma, Newton, 1992, p. 33-34.

${ }^{26}$ Idem, ibidem, p. 34. 
L'onorevole Scipioni e L'uomo di lusso, somente as duas primeiras e parte da terceira foram concluídas.

O prefácio de Os Malavoglia foi redigido um mês antes da publicação do livro, e especialmente recomendado ao editor. Isso indica que o texto já tinha sido planejado como parte indissociável da obra, e sua ideação foi-se maturando ao longo da redação do romance. "Em qualquer livro, o prefácio é, ao mesmo tempo, a primeira e a última palavra. Serve para explicar o objetivo da obra ou para justificar e responder às críticas", observa Liérmontov. ${ }^{27}$ No prefácio de Os Malavoglia, a voz do autor implícito ${ }^{28}$ é veiculada por uma instância narrativa de estilo naturalista, que, ao apresentar a intenção programática, os conceitos e os métodos do escritor verista, resgata suas raízes na tradição literária, ao mesmo tempo que projeta suas funções artístico-sociais na trajetória da literatura contemporânea.

O prefácio orienta a leitura para as questões específicas do romance, evidenciando seus principais aspectos e traços constitutivos. Trata da organicidade da obra verista, justificando a escolha do objeto e dos critérios que regem sua representação, e discorre sobre o modus operandi do narrador impessoal. Sustenta a unidade orgânica e promove a "afinidade e a coesão" 29 da obra, porque expõe os princípios básicos que "darão vida a todos os setores, colorindo cada um com suas particularidades qualitativas próprias". ${ }^{30}$ Como definição do método de criação verista, que visa à reprodução artística exata da realidade, os preceitos nele apresentados dão ensejo a um processo de composição metonímico, de acordo com o qual, forma e conteúdo são atravessados por um único princípio de representação, que resulta e reverbera no todo. Desse ponto de vista, evidencia-se a concepção de Os Malavoglia como um romance-tese, pois é possível entrever que a força integradora de sua organicidade permite que na obra coexistam ativamente o romance verista e a tese desse romance.

O prefácio explica o método de observação do narrador para representar o objeto de maneira incontaminada, preservando suas particularidades. O narrador verista é idealizado como um observador imparcial que, ao contar a história de uma família siciliana subjugada às condições do presente histórico, restitui a "cena nitidamente, com as cores devidas, de modo a dar a representação da realidade como ela foi". ${ }^{31}$ Para tanto, ele procura identificar-se com o seu objeto de representação, colocando-se como um observador arrastado pela mesma cheia, que olha "ao seu redor", com interesse "pelos fracos que ficam pelo caminho". ${ }^{32}$ Representar a realidade em toda sua complexidade, através de uma instância narra-

${ }^{27}$ Em Liérmontov, "Prefácio do autor", in O herói do nosso tempo, Rio de Janeiro, Ed. Guanabara, 1988 , p. 11.

${ }^{28}$ Cf. H. Grosser, Narrativa - Manuale / Antologia, Milano, Principato, 1985, p. 44.

${ }^{29}$ Cf. G. Verga, "Lamante di Gramigna", op. cit., p. 204.

${ }^{30}$ Cf. S. Eisenstein, Reflexões de um cineasta, Rio de Janeiro, Zahar Editores, 1969, p. 62.

${ }^{31}$ G. Verga, "Prefácio", in Os Malavoglia, trad. Aurora Fornoni Bernardini e Homero Freitas de Andrade, São Paulo, Ateliê Editorial, 2002, p. 10.

${ }^{32}$ Idem, ibidem, p. 9 
tiva despersonalizada e imparcial, que seja capaz de deixar o objeto falar por si, é o cerne da problemática naturalista, e também a questão para a qual o romancetese propõe uma solução.

A história de Os Malavoglia se passa entre 1860 e o final da década de 1870, no vilarejo de Aci Trezza, região natal de Verga. O período, que compreende os anos em que o escritor foi soldado e jornalista, é considerado um dos mais conturbados e sangrentos da Unificação italiana; especialmente na Sicília, onde a Guardia Nazionale e o exército de Garibaldi, depois de derrotarem a resistência bourbônica, combateram violentamente numerosos bandos de camponeses rebelados em decorrência da miséria. A luta estendeu-se por cinco anos (1860-1865) e resultou no massacre de milhares de vítimas dos dois lados. ${ }^{33}$

No prefácio ao romance, valendo-se de uma metáfora explícita dos conflitos internos, o autor define a obra como um relato objetivo da realidade dos vencidos, que "levantam os braços desesperados, e dobram a cabeça sob o pé brutal dos que sobrevêm". ${ }^{34}$ Ele se apresenta como um observador que se retira "um instante para fora do campo da luta para estudá-la sem paixão". ${ }^{35}$ Os Malavoglia reconstituem a realidade dos mais fracos durante um acontecimento histórico recente: a primeira edição do romance dista apenas duas décadas da fase mais violenta da Unificação italiana. O tema era atualíssimo e polêmico. O modo de tratá-lo também, pois seguia o receituário naturalista, segundo o qual "os caracteres, as atitudes e as relações das personagens atuantes devem estar estritamente ligados às circunstâncias da história da época". ${ }^{36}$ Para tanto, as condições políticas e sociais do momento histórico contemporâneo são enredadas na trama narrativa, de modo a contribuir para a restituição fidedigna do "espetáculo", e alcançar, como Verga pretendia, a "representação da realidade como ela foi, ou como deveria ter sido". ${ }^{37}$ No romance, é representada uma comunidade de pescadores isolada do mundo. O narrador relata detalhadamente sua vida diária, reproduz seu modo de falar e descreve seus usos, costumes, ofícios, crenças e marcas culturais. As circunstâncias que compõem a vida da sociedade ficcional são expostas, e, aos olhos do leitor, descortina-se um quadro humano muito significativo, que remete às verdadeiras condições sociais, políticas e econômicas que determinam a vida da população siciliana.

O contexto sociopolítico real da Sicília pós-unitária deixa-se entrever na narração de certos episódios, como a revolta dos aldeões contra o imposto sobre o piche, além daquele já cobrado sobre o sal; o alistamento obrigatório no serviço militar de dois irmãos Malavoglia, cuja partida da terra natal debilita a força de trabalho da família; a morte de um deles durante uma batalha naval ocorrida,

${ }^{33}$ Cf. A. Pagano, "1862 - Cronologia di un anno infame - La pulizia etnica piemontese nelle Due Sicilie", disponível em: <http://www.cronologia.it>.

${ }^{34}$ G. Verga, "Prefácio", in Os Malavoglia, op. cit., p. 9.

${ }^{35}$ Idem, ibidem, p. 10.

${ }^{36}$ Cf. E. Auerbach, Mimesis, op. cit., p. 408.

${ }^{37}$ G. Verga, "Prefácio", in Os Malavoglia, op. cit., p. 10. 
de fato, em 1866; a epidemia de cólera que mata a mãe da família, e que, na realidade, alastrou-se pela região em 1867; a incompetência administrativa do prefeito e do secretário da província que, em vez de defenderem interesses da população, favorecem causas próprias. Ademais, no decorrer da história, algumas personagens aludem a personalidades do cenário político da época: os Bourbons, Franceschello (apelido do rei Francesco II, deposto em 1860), Garibaldi, Vittorio Emanuele II. A partir da identificação na narrativa de elementos reais do cenário sócio-político-econômico do país, estabelecem-se pontos de contato entre o enredo romanesco e o processo histórico real. À medida que a leitura do romance desvela o desamparo da sociedade ficcional, oferece também subsídios para a compreensão da situação concreta da população siciliana à época.

Os Malavoglia fazem um recorte antropológico da sociedade siciliana no ápice da Unificação italiana; e a versão oficial desse processo histórico, registrada em documentos governamentais e ilustrada em livros didáticos, diferia muito da realidade representada no romance. Isso se deve especialmente ao fato de o narrador-observador adotar o ponto de vista da classe subjugada. Conforme o autor explica no prefácio, o enfoque particularizado evidencia aspectos pouco nobres do "espetáculo", ${ }^{38}$ os vícios e as fraquezas que o movem. Tal perspectiva opõe-se à visão do conjunto, que tende a diluir os pormenores inconvenientes e a representar tão somente a grandiosidade do todo, como sói acontecer em relatos tradicionais de história, ou mesmo em romances históricos convencionais. O aspecto documental da narrativa literária propõe ao leitor, de qualquer época ou país, uma leitura amarrada à realidade histórica, que o leva a enxergar-se como peça do mesmo quadro da civilização humana. Nesse sentido, a função artístico-social do romance verista satisfaz o propósito educativo que a inspira. No plano sociocultural, Os Malavoglia são a contraversão da história oficial da Sicília pós-unitária, justamente por contá-la da perspectiva dos vencidos; e no plano artístico, um paradigma literário inédito, pois a adoção do novo objeto artístico, aliada a um enfoque narrativo original, propõe uma série de procedimentos que subvertem a rigidez da literatura italiana oitocentista.

A noção de objeto artístico como objeto de estudo literário está relacionada com a função que a literatura, especialmente a naturalista, criou para si dentro da cultura burguesa europeia do século XIX. Esse tipo de expressão literária privilegia o fator social no processo de criação, de modo que o vocabulário do universo representado recebe tratamento estilístico cuidadoso na composição do sistema linguístico da obra. Para Auerbach, a inserção da língua vulgar na narrativa literária foi fundamental para tratar com seriedade o cotidiano real das pessoas sem importância. ${ }^{39}$ Os estudos de Bakhtin concordam com tal proposição, ao sustentar que o tratamento literário sério aplicado à vida do homem

\footnotetext{
${ }^{38}$ G. Verga, "Prefácio", in Os Malavoglia, op. cit., p. 10.

${ }^{39}$ Em E. Auerbach, Mimesis, op. cit., p. 26.
} 
comum só se dá a partir do rebaixamento da língua literária culta e da mistura dos níveis de linguagem. ${ }^{40}$

Tudo indica que desde a primeira ideia que inspirou o romance Os Malavoglia, Verga tinha em mente a preocupação de elaborar uma solução linguística que fizesse jus à proposta de representação realista do objeto. Em carta de setembro de 1875, ele comunicava ao editor Emilio Treves que estava trabalhando num "esboço marinheiresco" intitulado Padron "Ntoni (texto que deu origem ao romance). ${ }^{41}$ É bem provável que, conforme o escritor relatou ao jornal Tribuna em 1911, a origem desse esboço remonte a um "acaso verídico" que lhe ocorrera. ${ }^{42}$ Segundo a entrevista, Verga conta que certa vez caiu-lhe em mãos um jornal de bordo que narrava as peripécias de um capitão em seu veleiro, e muito o intrigou, pela concisão e total falta de cuidados gramaticais: "Golpeou-me, reli-o: era o que eu procurava sem distintamente me dar conta. Às vezes, sabe-se, basta um ponto. Foi um facho de luz". ${ }^{43} \mathrm{O}$ fato de a primeira pedra do romance ser um material não literário, de cunho regionalista e escrito num registro linguístico específico da lida marinheira, demonstra que Verga pretendia extrair a ficção da vida real, tinha a atenção voltada a determinada problemática sociogeográfica (no caso, da sua região natal), e preocupava-se com a questão da língua literária.

Dessa perspectiva, há que considerar outro traço essencial do romance, que advém do interesse do autor pela narrativa popular, despertado por uma "pequena obra-prima" de Capuana, o divertido conto "Lu cumpari", o qual retoma o mote de uma velha canção folclórica. ${ }^{44}$ Em carta de 1882, Verga confessava ao amigo que devia a ele a "primeira inspiração da forma genuinamente popular" 45 que tinha procurado dar a suas novelas. Enquanto escrevia o romance, Verga trocava ideias sobre o seu trabalho com Capuana, pedindo sugestões de ditos e injúrias da tradição oral, bem como indicações de antologias e dicionários de provérbios e modos de falar do dialeto siciliano. ${ }^{46}$ Havia algum tempo, Capuana dedicava-se à pesquisa de clássicos da literatura italiana, de narrações populares e provérbios sicilianos, a fim de definir as perspectivas ideológico-verbais de uma língua literária que representasse com autenticidade o mundo popular das províncias meridionais, e fosse compreendida pelo público leitor concentrado nas regiões privilegiadas do país. "Ah, a língua!... O nosso gravíssimo escolho!", ${ }^{47}$ desabafaria

${ }^{40}$ Em M. Bakhtin, Questões de literatura e de estética..., op. cit., p. 409.

${ }^{41}$ Apud C. Simioni, "Introduzione", op. cit., p.13.

${ }^{42}$ Cf. E. Sanguineti, Cronologia della vita e delle opere" (Prefazione), in G. Verga, I Malavoglia, Roma, Editori Riuniti, 1982, p. xxvi.

${ }^{43}$ Apud C. Simioni, "Introduzione", op. cit., p.14.

${ }^{44}$ Cf. G. Verga, Lettere a Luigi Capuana, op. cit., p. 201.

${ }^{45}$ Idem, ibidem, p. 200.

${ }^{46}$ Idem, ibidem, p. 93 (carta de 17 mai. 1878); p. 121 (10 abr. 1879).

${ }^{47}$ Apud G. Petronio, L'attivitá letteraria in Italia, op. cit., p. 716. O termo utilizado por Capuana, "scoglio", foi aqui traduzido literalmente, para manter a referência aos escolhos, ou "farilhões dos Ciclopes", situados em Aci Trezza, que, na literatura verguiana são associados à limitação, desgraça, perigo (cf. p. 19, "o ideal da ostra"). 
Capuana ao relembrar o trabalho que teve, durante a redação de Giacinta, para chegar a uma solução estilística eficaz. Além de recorrer ao amigo, Verga planejou passar algumas semanas em Aci Trezza, logo que terminasse de escrever o romance, para dar o tom local à narrativa..$^{48}$ De lá escreveu a Capuana, contando que aproveitava a estada à beira-mar para observar de perto "aqueles pescadores e colhê-los vivos como Deus os fez". ${ }^{49}$

Ao incorporar no processo de criação do romance linguagens de outros gêneros textuais e da tradição oral - o diário de bordo, os contos popularescos, o linguajar dos marujos, o modo de falar dos habitantes de Trezza, os rifões da sabedoria popular siciliana - o autor implanta na sua gênese o plurilinguismo,$^{50}$ que ressoa em todos os seus elementos formais e conteudísticos. A organização do diálogo interno das diversas linguagens sociais relativas às áreas de atuação e aos sistemas ideológico-culturais da comunidade linguística representada define a "estilística sociológica" ${ }^{51}$ do romance. Trata-se de uma revolução muito importante nos domínios da literatura, porque liberta a expressão artística do poder arbitrário de uma língua literária única. Uma batalha particularmente difícil no campo da literatura italiana do século XIX, onde o romance era considerado um gênero secundário, e predominava uma língua literária conservadora e refratária ao coloquialismo e aos dialetos regionais. A proposta verista perseguia o ideal da impessoalidade narrativa, cujo objetivo era deixar as personagens populares falarem por si, sem o intermédio de um narrador que elevasse o discurso ao nível do autor burguês. Por relegarem a tradição da língua literária culta, os escritores veristas foram, durante um bom tempo, taxados de maus escritores pela maior parte dos leitores e da crítica da época.

A língua literária que Giovanni Verga criou em Os Malavoglia resultou no "instrumento mais perfeito e eficaz que o estilo narrativo conheceu na Itália por meio século", 52 resume Antonio Candido, expressando uma opinião que se afina com a da crítica italiana atual. No prefácio ao romance, o autor explicita os critérios da sua criação linguística. Há que considerar o desejo sincero de "demonstrar a verdade", e então, para que o quadro social explorado possa ser representado de modo realista, é essencial imprimir no discurso a marca genuína da língua falada da comunidade retratada. Deve-se levar em conta o fato de que "a linguagem tende a individualizar-se, a enriquecer-se de todas as meias tintas, dos meios sentimentos, de todos os artifícios da palavra para dar relevo à ideia". Para que a reprodução artística seja exata, prossegue o autor, é preciso "seguir escrupulosamente as normas desta análise", pois, no seu entender, "a forma é tão inerente ao sujeito, quanto cada parte do próprio sujeito é necessária à explicação do argumento

\footnotetext{
${ }^{48}$ Cf. G. Verga, Lettere a Luigi Capuana, op. cit., p. 93 (carta de 17 mai. 1878).

${ }^{49}$ Idem, ibidem, p. 114 (carta de 14 mar. 1879).

${ }^{50}$ Cf. M. Bakhtin, Questões de literatura e de estética..., op. cit., p. 107-133.

${ }^{51}$ Idem, ibidem, p. 106.

${ }^{52}$ Em "O mundo-provérbio", in G. Verga, Os Malavoglia, op. cit., p. 348.
} 
geral" ${ }^{53} \mathrm{O}$ discurso narrativo do romance é construído de acordo com o vocabulário e a sintaxe da língua falada dos moradores da aldeia siciliana. A solução estilística de Verga combina a língua culta com a rústica, e o seu narrador trabalha com quatro possibilidades linguísticas: "toscano culto, toscano popular; siciliano eventualmente submetido a tratamento literário, siciliano popular" ${ }^{54} \mathrm{O}$ ritmo da oralidade e o lugar-comum típicos do dialeto local evidenciam-se, na narrativa, pela reprodução de provérbios, expressões idiomáticas, frases feitas, jargões do trabalho e da lida doméstica; bem como, pela criação e uso recorrente de epítetos, formulados com elementos do senso comum da comunidade retratada.

A língua do romance é articulada através de um narrador em terceira pessoa que continuamente rompe as formas fixas da enunciação, ${ }^{55}$ suprimindo as convenções sintáticas dos discursos direto, indireto e indireto livre, e nivelando as vozes do narrador e das personagens num só plano discursivo. Em carta a Edouard Rod, tradutor de Os Malavoglia para o francês, Verga mostrava-se plenamente ciente de que a língua literária que criara era inédita na literatura italiana, e enfatizava que sua intenção fora exprimir com nitidez a língua local, preservando-lhe ao máximo o tom verdadeiro e a marca própria. ${ }^{56}$ De fato, é a força da expressão social da língua do romance que o configura como uma consciência linguística ativa e participante do processo de evolução da língua literária italiana. ${ }^{57}$ No plano estrutural da narrativa, a língua é peça-chave que faz convergir os recursos estilísticos empregados pelo autor para a construção do narrador impessoal, e de uma verossimilhança narrativa perfeitamente orgânica.

Os ideais naturalistas, relativos a um narrador e uma língua literária que deixam o objeto falar por si, são plenamente contemplados no romance de Verga. De acordo com Roman Jakobson, toda inovação artística que se propõe a uma maior aproximação da realidade deforma ao máximo os cânones artísticos; ${ }^{58}$ e a partir dessa perspectiva, pode-se considerar que Os Malavoglia, ao desenvolverem uma série de procedimentos artísticos inovadores, contribuíram para a deflagração de uma crise do gênero no âmbito da literatura italiana. A língua malavogliana, como instrumento de representação realista da sociedade da província siciliana, promove uma revolução que está intimamente ligada ao processo de Unificação italiana. Ela integra língua literária convencional e língua dialetal, e nesse gesto simbólico propõe a legitimação das várias identidades culturais das regiões italianas. Ao organizar diferentes vozes sociais de uma só nação, a língua do romance ganha

${ }^{53}$ G. Verga, "Prefácio", op. cit., p. 8.

${ }^{54}$ Cf. A. Candido, "O mundo-provérbio", in O discurso e a cidade, São Paulo, Duas Cidades, 1993, p. 348.

${ }^{55}$ Cf. M. Bakhtin, Marxismo e filosofia da linguagem - Problemas fundamentais do método sociológico na ciência da linguagem, São Paulo, Hucitec, 1999, p. 139-143.

${ }^{56}$ Cf. A. Candido, "O mundo-provérbio", op. cit., p. 349.

${ }^{57}$ Cf. M. Bakhtin, Questões de literatura e de estética..., op. cit., p. 164-210.

${ }^{58}$ Cf. R. Jakobson, "Do realismo artístico", in Teoria da Literatura - Formalistas russos, Porto Alegre, Globo, 1971, p. 122-123. 
dimensão política, e define a sua função artístico-social. $\mathrm{O}$ romance-tese propõe a unificação da literatura italiana, pois, ao conferir dignidade literária à língua, a temas, motivos e personagens da Sicília, rompe a hegemonia artística setentrional.

Ao tratar a questão da impessoalidade no romance moderno, em "Lamante di Gramigna", Verga ousou ir além da proposta lançada em "Fantasticheria", onde convidava o leitor a observar o objeto artístico por intermédio do microscópio. Em "Lamante di Gramigna", sua intenção é deixar que o leitor depare com "o fato nu e genuíno", 59 não submetido à lente do escritor - não há mais barreira que separe o leitor-observador do objeto de representação. Na resenha que fez a Os Malavoglia, Capuana alega que a questão da impessoalidade narrativa era o alvo supremo das ambições dos romancistas da época. Numa carta que escreveu a Capuana em fevereiro de 1881, Verga se referia à sua "velha fixação" 60 pela impessoalidade da obra de arte. Na sua opinião, a obra bem sucedida é um organismo vivo, completo, imortal, e, portanto, muito mais valiosa do que o artista que a criou. Para defender a ideia junto ao amigo, colocou-lhe as seguintes questões: "Che cosa è non il tuo nome, né il mio, ma quel del Manzoni, o di Zola, in faccia ai Promessi Sposi e dell'Assommoir? L'opera d'arte non val più dell'autore?". ${ }^{61}$ Verga fez questão de prenunciar que a arte do futuro deveria, de maneira universal, admitir o total desapego pelo artista. A Salvatore Farina, Verga afirmou que o triunfo do romance seria alcançado quando a organicidade de suas partes fosse tão perfeita, e a sua matéria, tão necessária, que a "mão do artista" permaneceria totalmente invisível, de modo que a obra teria "a marca do acontecimento real" e pareceria "ter sido feita por si", como um "fato natural", que nasce sem conservar nenhum ponto de contato com o autor-criador. Tais declarações denotam que o escritor refletia sobre a evolução do romance moderno e participava de tendências e ideias artísticas originais em seu tempo.

Em literatura, o ideal da impessoalidade recai sobre o narrador: os esforços do autor convergem para não se deixar entrever o narrador na matéria narrada. A "emancipação do romance em relação ao objeto"62 é limitada justamente pela linguagem discursiva, a qual, por sua vez, é o único instrumento de que o narrador dispõe para contar a história. Superar tal limitação depende da força criativa da técnica de representação desenvolvida no discurso do narrador para iludir o leitor de que a voz narrativa é o próprio objeto. Dessa perspectiva, compreende-se como a construção bem sucedida do narrador verista, que não se deixa detectar com facilidade, está intimamente vinculada à aplicação maciça do princípio de verossimilhança ao sistema linguístico-discursivo do romance. O objeto de representação artística parecerá autêntico ao leitor, na mesma medida em que a voz narrativa

${ }^{59}$ Em G, Verga, "Lamante di Gramigna”, op. cit., p 203.

${ }^{60}$ Apud R. Scrivano, La narrativa di Giovanni Verga-appunti per le lezioni di letteratura italiana, Roma, Bulzoni Editore, 1981, p. 137 (carta de 19 fev. 1881).

${ }^{61}$ Idem, ibidem.

${ }^{62}$ Cf. T. Adorno, Notas de literatura I, São Paulo, Livraria Duas Cidades, Editora 34, 2003, p. 56. 
também soar natural e legítima, por se expressar numa linguagem identificada com o universo sociocultural representado.

Verga trabalhou nos contos de Vita dei campi e no romance Os Malavoglia sempre com o propósito de alcançar a impessoalidade narrativa. Os contos podem ser considerados etapas experimentais da composição do narrador impessoal, almejado pelo autor, e alcançado no romance de maneira inigualável, como avaliou Capuana, na já referida resenha. Em "Lamante di Gramigna", ao propor a reprodução fiel de uma narração popular de caráter histórico, Verga lança os fundamentos da construção do seu narrador. Ele informa que apenas repetirá a história ouvida, preservando-lhe as palavras "simples e pitorescas". ${ }^{63}$ Segundo Benjamin, "a experiência que anda de boca em boca" ${ }^{4}$ é a fonte de todos os narradores, e ao recorrer diretamente a ela, Verga investe na despersonalização do seu narrador, valendo-se do princípio de que a história escrita que provém da tradição oral popular tende a preservar-lhe o espírito de anonimato, justamente porque procura não se distinguir "do discurso dos inúmeros narradores anônimos". ${ }^{65}$

O detalhe significativo do método realista de representação literária que Verga inventou em Os Malavoglia fica por conta do apelo às raízes. Nesse método, a paródia e a estilização são as operações essenciais, utilizadas como mecanismos de despersonalização e isenção narrativa. De uma perspectiva processual, o recurso vale-se da força arquetípica dos mitos que a narrativa recupera. Os arquétipos, por atuarem na esfera do inconsciente coletivo, atingem em cheio o leitor, cuja energia psíquica, num processo de identificação sensível-intuitiva, é ativada pelo simbolismo que a narrativa propõe. Sem dúvida, esse é um recurso poderoso para suprimir as barreiras que costumam delimitar as relações convencionais entre autor, obra e leitor. ${ }^{66}$

Como instância mediadora dessa tríade, o narrador de Os Malavoglia se oculta do leitor, não por se diferenciar dele, do mesmo modo como não se diferencia das personagens; mas, ao contrário, por uma espécie de contaminação mimética. Em relação às personagens, esse processo se dá pela representação paródico-estilizada de elementos da realidade da comunidade retratada (linguagem, cultura, crença, mentalidade, valores morais, situações cotidianas e do trabalho etc.). Já no que diz respeito ao leitor, a tarefa de aproximação do narrador ocorre a partir da representação, também paródica, de temas arquetípicos (mitos, legendas, sabedoria popular, tradição oral, literaturas antiga, clássica e popular) que apelam a esferas subliminares de generalidade e primordialidade; de modo a fazer que o leitor identifique-se com a história narrada, a ponto de ter a impressão de estar circunscrito àquele universo, que mesmo sendo outro é o seu, pois a expressão artística irradia a essência do gênero humano.

${ }^{63}$ Em G. Verga, "Lamante di Gramigna”, op. cit., p. 203.

${ }^{64} \mathrm{~W}$. Benjamin, "O narrador - observações acerca da Obra de Nicolai Leskow", in Textos escolhidos, São Paulo, Abril, 1980, p. 58.

${ }^{65}$ Idem, ibidem.

${ }^{66}$ Cf. A. Candido, Literatura e sociedade, São Paulo, T. A. Queiroz Editor, 2000, p. 22. 
O prefácio coloca que o narrador verista privilegia a observação de perto, dos detalhes, para evidenciar "todas as contradições, de cujo atrito brota a luz da verdade" ${ }^{67}$ Tal proposição anuncia o princípio paródico que rege o método de representação do romance. De acordo com ele, o plano da obra é sobreposto ao plano do elemento parodiado, e para que a paródia possa alcançar sua intenção reveladora, faz-se necessária a "desarticulação dos dois planos, o deslocamento de ambos" ${ }^{68}$ a fim de que se dê o "atrito" revelador, aquele que dá chance à percepção da verdade subjacente da coisa. Ao retratar o cotidiano duro e a vida desgraçada da família Malavoglia e dos habitantes da aldeia, Verga disseca aos olhos do leitor o seu objeto de estudo, reservando-se o direito, outorgado pelo escrúpulo cientificista, de não julgar as chagas sociais que expõe. No entanto, graças à continuidade de seu estilo, a paródia estabiliza-se como o princípio organizador do romance; e a função artístico-social que tal mecanismo desempenha distingue-se por articular a crítica ao caso social representado de maneira oblíqua, porque o princípio de criticidade reside no próprio método de criação literária, que recorre a procedimentos paródicos para representar a realidade de forma séria. Desse modo, são engendradas na narrativa estratégias de ruptura, desconstrução, revolução dos padrões artísticos e axiológicos convencionais. Essa maneira de colocar as coisas revela-se bastante inteligente e democrática: Verga delega ao leitor a tarefa nada fácil de decifrar as nuanças ideológicas do discurso narrativo e atribuirlhes sentido próprio, de um modo que, apesar de o leitor ter a impressão de fazer o percurso sozinho, caminha o tempo todo pela trilha aberta pelo narrador, e nesse caso, está sempre ao lado dos vencidos.

A paródia, em razão do princípio de duplicidade que a caracteriza, apresentase como a única possibilidade de recriação crítica do quadro social retratado. $\mathrm{Na}$ representação do momento histórico, a população de Aci Trezza está à margem do desenvolvimento tecnológico e da urbanização do século XIX, e vive o presente à moda antiga, de acordo com o regime de vida dos antepassados. A partir dessa perspectiva, percebe-se que em Os Malavoglia o presente é paródia do passado. A retrógrada aldeia siciliana, que subsiste numa época de progresso rápido e ideias avançadas, só pode ser descrita pela paródia do mundo antigo, estático e de pensamento absoluto. Em uma mesma operação paródica de representação, é possível combinar elementos opostos, que coexistem nesse universo, e, ao se sobrepor o plano da antiguidade ao da atualidade, este último, por estar em vigor, desnuda-se em profundidade. Ainda mais interessante é notar que as categorias e qualidades que a paródia introduz no romance se chocam contra os princípios positivistas e o engajamento social do naturalismo literário nos quais a obra se fundamenta, pois essa desarticulação propõe uma revisão crítica profunda da realidade artística e social.

\footnotetext{
${ }^{67}$ G. Verga, "Prefácio", op. cit., p. 9.

${ }^{68}$ Cf. Tyniánov, "Dostoevskij e Gogol': per una teoria della parodia”, in Avanguardia e Tradizione, Bari, Dédalo Libri, 1968, p. 138
} 
Tudo isso leva a crer que apesar da afinidade com a escola naturalista e da colaboração decisiva para a construção do verismo, Verga não amarrou sua produção literária nem a uma coisa, nem a outra. Avesso a rótulos, o escritor sempre se destacou por uma consciência artística autônoma. Haja vista o caso de Os Malavoglia, que contemplam plenamente os preceitos naturalistas e estabelecem-se na literatura italiana como protótipo do romance verista, mas, ao mesmo tempo, extrapolam a própria prédica que os inspirou, porque revolucionam os padrões artísticos da época e experimentam uma nova arte, antecipando a paródia como método de representação realista que caracterizaria o romance do século XX. 